\title{
INTRODUKSI PENGOLAHAN RUMPUT LAUT MENJADI BAKPIA DI DESA LEMBONGAN, KABUPATEN KLUNGKUNG
}

\author{
Ni Nyoman Puspawati ${ }^{1}$, I Made Sugitha ${ }^{2}$, Ni Wayan Wisaniyasa ${ }^{3}$
}

\begin{abstract}
ABSTRAK
Kabupaten Klungkung merupakan Kabupaten yang paling kecil dari 9 (sembilan) Kabupaten dan Kodya di Provinsi Bali. Wilayah Kabupaten Klungkung sepertiganya terletak di daratan Pulau Bali (11.216 Ha) dan dua pertiganya terletak di Kepulauan Nusa Penida (20.284 Ha) dan Nusa Lembongan.Nusa Lembongan merupakan pulau kecil yang terletak berdekatan dari pulau Nusa Ceningan dengan jarak sekitar $2 \mathrm{~km}$ di sebelah Barat laut Nusa Penida. Mata pencaharian sebagian besar penduduk Nusa Lembongan adalah sebagai petani rumput laut dan sebagian bekerja di sektor pariwisata. Rumput laut merupakan komoditi pertanian utama yang dihasilkan Nusa Lembongan.Pada tahun 2009 produksi rumput laut mencapai 106.188 ton meningkat sekitar 10,83\% dibanding tahun sebelumnya. Masyarakat di Desa Lembongan hanya menjual rumput laut dalam bentuk segar ataupun setelah dikeringkan tanpa dilakukan pengolahan lebih lanjut. Pemanfaatan rumput laut menjadi bakpia rumput laut dengan memanfaatkan hasil penelitian belum diketahui oleh warga desa. Penyuluhan, pelatihan dan pengenalan proses pengolahan rumput laut menjadi produk olahan rumput laut diharapkan dapat meningkatkan nilai ekonomis rumput laut dan dapat meningkatkan kesejahteraan petani rumput laut. Selain memiliki potensi hasil pertanian rumput laut yang besar, Desa Lembongan juga merupakan daerah yang memiliki potensi pariwisata alam khususnya pantai yang sangat indah. Dengan adanya usaha pengolahan rumput laut menjadi produk pangan maka produk-produk olahan tersebut dapat dipasarkan didaerah objek wisata tersebut sebagai produk khas Nusa Lembongan oleh-oleh bagi wisatawan, sehingga dapat menjadikan Desa Lembongan sebagai sentra pertanian rumput laut, industri pengolahan rumput laut serta pariwisata yang berpengaruh di Bali. Pengembangan Ipteks bagi masyarakat melalui pelatihan pengolahan rumput laut menjadi produk olahan bakpia rumput laut dapat memberikan tambahan pengetahuan dan keterampilan bagi kelompok laki tani dan wanita tani di desa Lembongan.
\end{abstract}

Kata kunci: Rumput laut, bakpia, diversifikasi pangan, nilai ekonomis

\section{PENDAHULUAN}

Kabupaten Klungkung merupakan Kabupaten yang paling kecil dari 9 (sembilan) Kabupaten dan Kodya di Provinsi Bali. Wilayah Kabupaten Klungkung sepertiganya terletak di daratan Pulau Bali (11.216 Ha) dan dua pertiganya terletak di Kepulauan Nusa Penida (20.284 Ha) dan Nusa

\footnotetext{
12,3 Jurusan Ilmu dan Teknologi Pangan, Fakultas Teknologi Pertanian, Universitas Udayana, Bukit Jimbaran, Badung Telp/Fax : 0361 701801. nnpuspa@yahoo.co.id
} 
Lembongan. Nusa artinya pulau. Nusa Lembongan merupakan pulau kecil yang terletak berdekatan dari pulau Nusa Ceningan dengan jarak sekitar $2 \mathrm{~km}$ di sebelah Barat laut Nusa Penida. Pulau Nusa Lembongan memiliki panjang 4 km dan lebar $1-1,5 \mathrm{~km}$, berada sekitar 11 km di sebelah Tenggara dari Pulau Bali.

Nusa Lembongan memiliki topografi permukaan tanah pada umumnya tidak rata, bergelombang bahkan sebagian besar berupa bukit-bukit terjal yang kering dan tandus dengan tekstur tanah berkapur sehingga disektor pertanian dan perkebunan penduduk setempat hanya mengandalkan tadah hujan karena kesulitan pasokan air. Daerah Nusa Lembongan merupakan salah satu kecamatan di kabupaten Klungkung yang masih dianggap daerah miskin dan banyak warganya yang bekerja di luar daerah. Mata pencaharian sebagian besar penduduk Nusa Lembongan adalah sebagai petani rumput laut dan sebagian bekerja di sektor pariwisata. Rumput laut merupakan komoditi pertanian utama yang dihasilkan Nusa Lembongan selain destinasi wisata yang sangat indah. Rumput laut merupakan komoditas ekspor andalan Kabupaten Klungkung (Wikipedia, 2010). Pada tahun 2009 produksi rumput laut mencapai 106.188 ton meningkat sekitar 10,83\% dibanding tahun sebelumnya.

Rumput laut di Desa Nusa Lembongan Kecamatan Nusa Penida mempunyai potensi yang sangat menjanjikan namun belum termanfaatkan secara optimal padahal rumput laut dapat juga digunakan sebagai suatu usaha produksi di bidang pangan oleh warga untuk menambah penghasilan keluarga miskin di Desa Nusa Lembongan. Rumput laut sangat mudah dibudidayakan dengan produksi yang sangat tinggi. Masyarakat di Desa Lembongan hanya menjual rumput laut dalam bentuk segar ataupun setelah dikeringkan tanpa dilakukan pengolahan lebih lanjut. Pemanfaatan rumput laut menjadi mie kering, krupuk, permen dan aneka manisan dengan memanfaatkan hasil penelitian belum diketahui oleh warga desa. Penyuluhan, pelatihan dan pengenalan proses pengolahan rumput laut menjadi produk olahan rumput laut diharapkan dapat meningkatkan nilai ekonomis rumput laut dan dapat meningkatkan kesejahteraan petani rumput laut.

Selama ini penggunaan rumput laut sebagai bahan pangan masih terbatas sehingga citranya dan nilai ekonomis rendah. Seiring dengan meningkatnya kesadaran masyarakat akan pentingnya 
pangan sehat maka tuntutan konsumen terhadap bahan pangan juga mulai bergeser. Bahan pangan yang kini mulai banyak diminati konsumen tidak hanya memiliki komposisi gizi yang baik serta penampakan dan cita rasa yang menarik, tetapi juga mempunyai fungsi fisiologis tertentu bagi tubuh. Salah satu produk olahan yang dapat dikembangkan dari rumput laut adalah kue bakpia.

Bakpia adalah makanan yang terbuat dari campuran kacang hijau dengan gula yang dibungkus dengan tepung lalu dipanggang. Bakpia termasuk makanan yang popular dari Cina atau Tionghoa. Kue bakpia pada umumnya dibuat dengan isian berbahan kacang hijau, namun dengan perkembangan jaman yang semakin pesat khususnya dibidang kuliner, dewasa ini bakpia dapat dibuat dari berbagai macam bahan seperti ketan hitam, coklat, keju dan ubi jalar ungu. Penggunaan rumput laut pada bakpia dapat dilakukan pada pembuatan kulit bakpia maupun sebagai bahan isiannya. Kandungan serat yang tinggi pada rumput laut dapat meningkatkan nilai gizi bakpia. Berdasarkan kelebihan dan sifat-sifat positif tersebut, rumput laut dinilai sangat sesuai untuk mendukung program diversifikasi pangan menuju swasembada pangan di abad 21.

\section{METODE DAN PEMECAHAN MASALAH}

Solusi yang ditawarkan kepada kelompok laki tani (KLT "Kerti Dharma") dan kelompok wanita tani (KWT "Segara Caksu") ini adalah memberikan penyuluhan dan pelatihan pengolahan rumput laut menjadi bakpia rumput laut. Produk ini merupakan hasil olahan rumput laut dengan cara pengolahan yang sangat sederhana.

Rumput laut di Desa Lembongan mempunyai potensi yang cukup menjanjikan namun belum dikembangkan dan dimanfaatkan dengan optimal dalam penganekaragaman produk olahan pangan. Pemanfaatan rumput laut menjadi bakpia belum diketahui oleh warga desa Lembongan, sehingga dalam kegiatan pengabdian ini dilakukan pelatihan pengolahan rumput laut ungu menjadi bakpia. Pelaksanaa kegiatan ini dilakukan melalui penyuluhan/pemaparan dengan pemberian makalah dan praktek pembuatan produk secara langsung dengan petani, anggota KWT Segara Caksu di desa Lembongan Kabupaten Klungkung. Proses pengolahan rumput laut menjadi bakpia dilakukan dengan cara yang sangat sederhana. rumput laut yang telah bersih dan direndam dalam air jeruk selanjutnya dihancurkan kemudian ditambah bahan-bahan pembantu selanjutnya dimasak menjadi bahan isian bakpia, sedangkan untuk kulit bakpia dibuat dengan 
bahan dasar terigu, margarin, gula dan air. Semua bahan-bahan kulit bakpia dicampur dan diuleni hingga kalis, selanjutnya bagi adonan kulit menadi bulatan-bulatan kecil sesuai keinginan. Pipihkan dan lipat adonan kulit secara berulng-ulang, kemudian tambahkan isian bakpia kemudian bungkus membentuk bulatan. Olesi bagian permukaannya dengan kocokan kuning telur. Tahap selanjutnya, panggang bulatan bakpia pada suhu $180^{\circ} \mathrm{C}$ selama 30 menit sampai matang dan berwarna kunging keemasan. Secara lebih jelas, proses pembuatan bakpia ubi jalar ungu dapat dilihat pada Gambar 1.

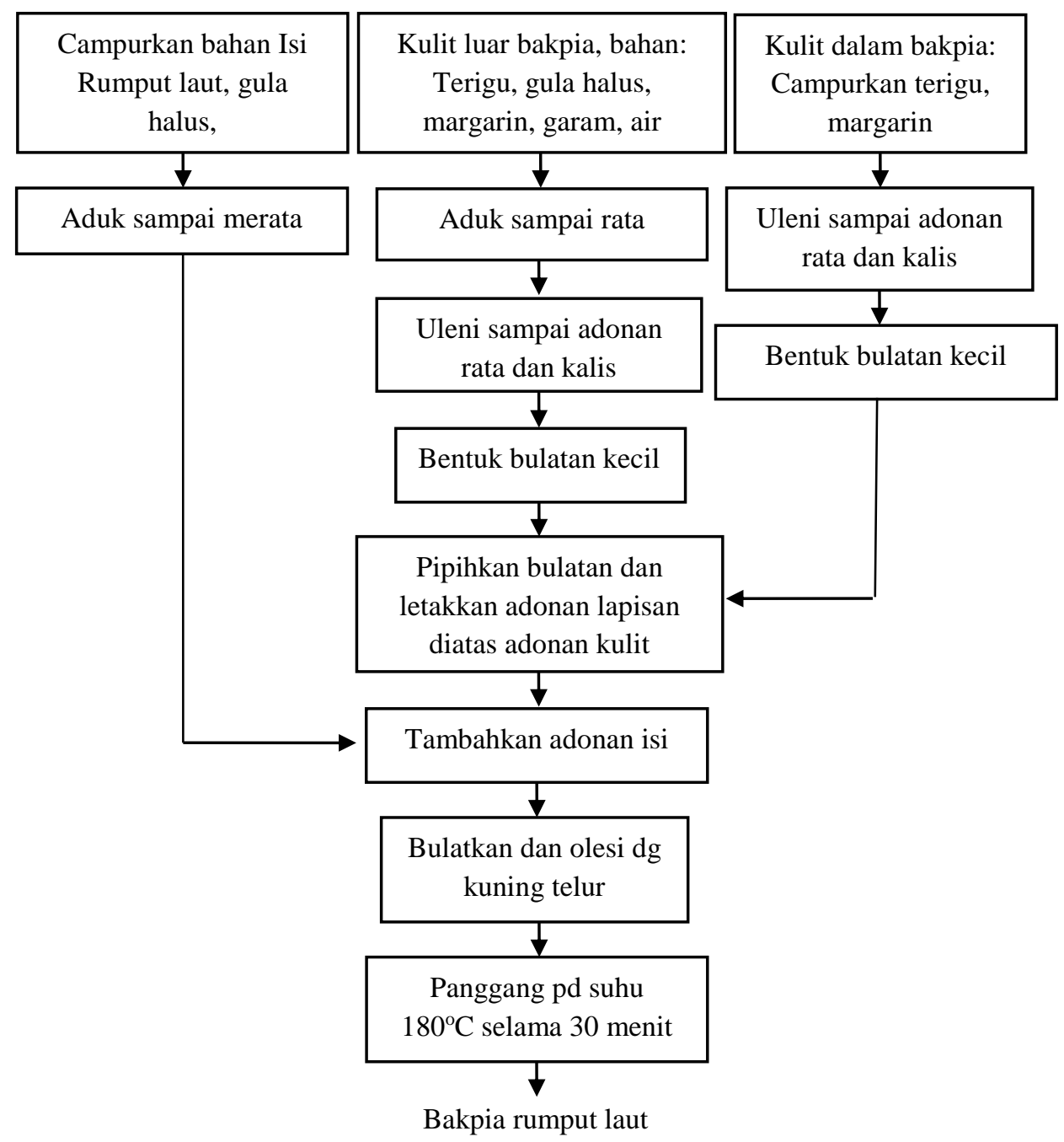

Gambar 1. Diagram alir pembuatan bakpia rumput laut 


\section{HASIL DAN PEMBAHASAN}

Bakpia rumput laut merupakan salah satu produk olahan dari rumput laut yang memiliki nilai gizi cukup tinggi. Rumput laut memiliki ciri dan bentuk yang beragam, salah satunya memiliki bentuk yang pipih, bulat dan bercabang. Dalam kandungan rumput laut itu sendiri mengandun nutrisi alami seperti vitamin $\mathrm{A}, \mathrm{B}_{1}, \mathrm{~B}_{2}, \mathrm{~B}_{3}, \mathrm{~B}_{12}, \mathrm{C}, \mathrm{D}, \mathrm{E}, \mathrm{F}, \mathrm{K}$, mineral dan asam lemak yang baik bagi tubuh. Dengan kandungan yang begitu komplit dalam rumput laut tersebut tidak heran jika rumput laut memiliki banyak manfaat bagi kesehatan dan kecantikan. Manaat rumput laut bagi kesehatan antara lain: mencegah aneia, menyehatkan system peredaran darah, menjaga system pencernaan, mengoptimalkan fungsi tiroid, kaya asam lemak omega 3, mencegah kanker, mencegah pengeroposan tulang, menjaga kesehatan kulit dan menaga system imun. Begitu besar manaat dan potensi rumput laut sehingga sangat membuka peluang dalam pengolahan dan peningkatan nilai ekonomis dari rumput laut itu sendiri.

Kegiatan pengabdian kepada masyarakat dalam bentuk pelatihan pengolahan rumput laut menjadi bakpia di Desa Lembongan, , Kabupaten Klungkung. Kegiatan ini dilaksanakan pada hari Kamis-Jumat, 28-29 Juli 2016 di Balai Desa Lembongan, Kabupaten Klungkung. Peserta pelatihan ini terdiri dari anggota kelompok laki tani "Dharma Kerti" dan kelompok wanita tani "Segara Caksu" di desa Lembongan. Kegiatan pengabdian dilakukan dalam bentuk penyuluhan dan praktek langsung pembuatan bakpia rumput laut. Proses pelatihan berjalan lancar dan sukses, hal ini ditunjukkan dengan respon peserta pelatihan sangat antusias mengikuti kegiatan karena masyarakat Desa Lembongan sangat memerlukan informasi dan pengetahuan tentang penerapan teknologi pengolahan rumput laut menadi bakpia, penganan yang memiliki nilai ekonomis tinggi. Peserta pelatihan melakukan proses pembuatan bakpia dengan semangat mengikuti arahan dari instruktur/tim pengabdian Universitas Udayana. Proses pelaksanaan kegiatan ini dapat dilihat pada Gambar 2.

Ketertarikan masyarakat mengikuti kegiatan ini juga disebabkan karena cara pembuatan bakpia rumput laut sangat mudah dan sederhana. Ini dapat dibuktikan dengan berhasilnya peserta membuat bakpia dengan citarasa, tekstur yang sangat baik dan dapat diterima secara sensoris. Pengolahan rumput laut menadi bakpia merupakan inovasi baru yang dilakukan di Desa Lembongan. Kegiatan pengabdian ini sangat bermanfaat dan tepat sasaran bagi khalayak yang 
dituju namun kedepan kegiatan ini harus terus dibina agar masyarakat mendapat dorongan dan dampingan/pembinaan untuk lebih mengembangkannya lagi dimasa yang akan datang sehingga dapat meningkatkan kesejahteraan masyarakat secara nyata dan signifikan. Pelaksanaan kegiatan pengabdian tersebut dapat dilihat seperti Gambar 2 .

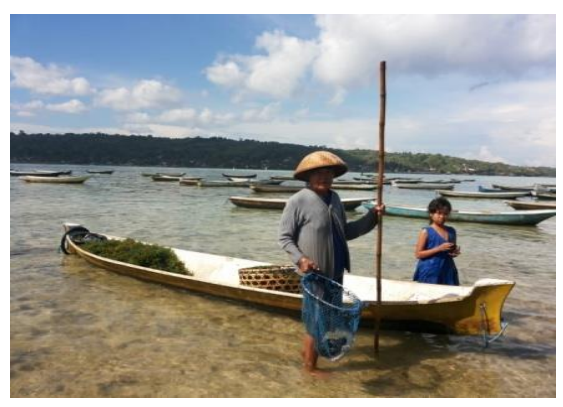

a. Petani rumput laut

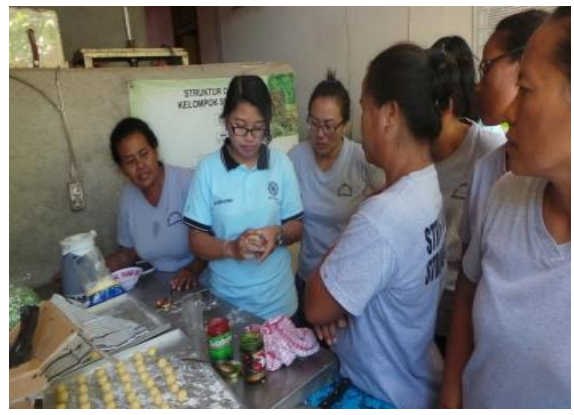

c. Pemipihan adonan

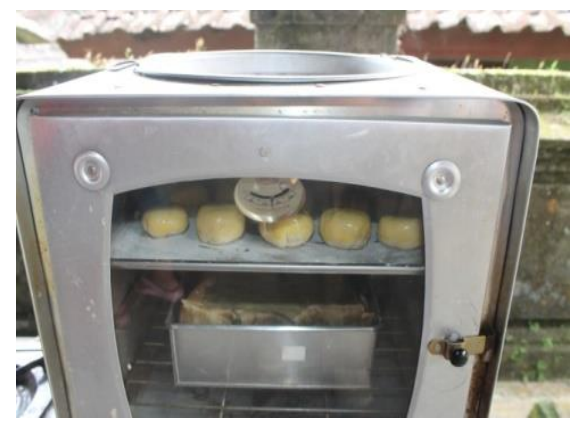

e. Pemanggangan Bakpia

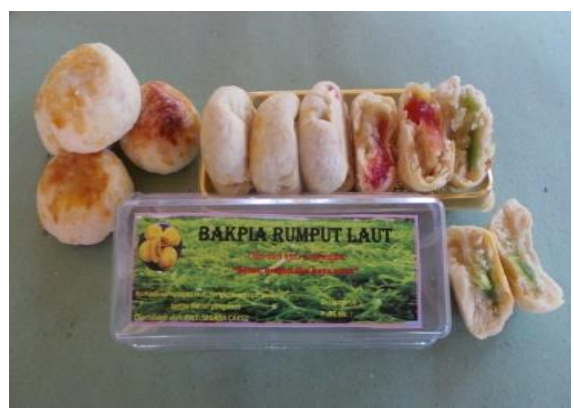

g. Bakpia rumput laut

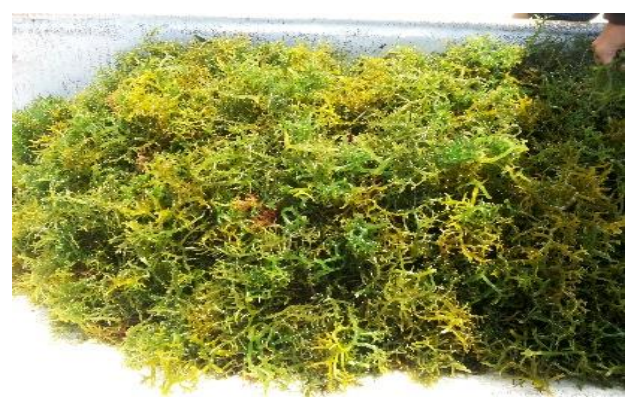

b. Rumput laut yang baru dipanen

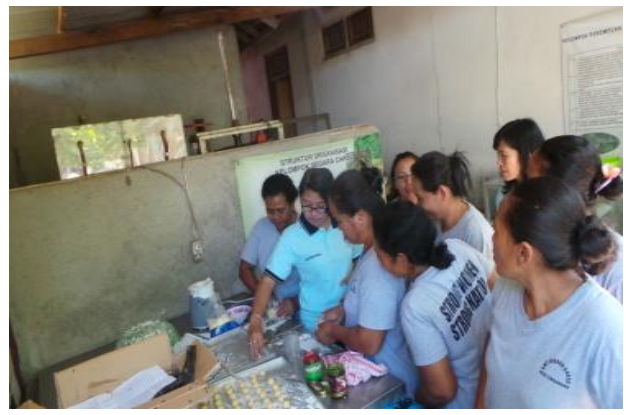

d. Pengisian bahan isian

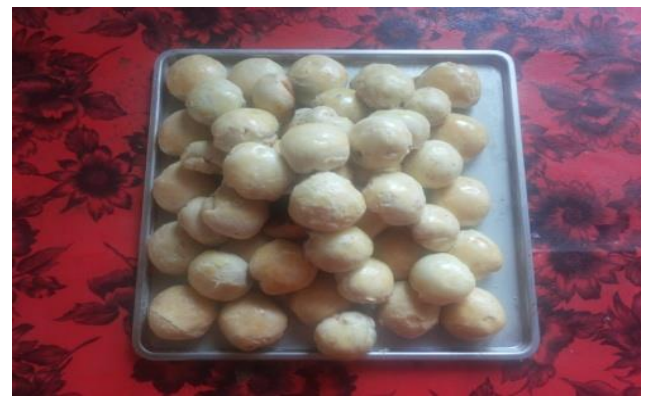

f. Bakpia yang siap dikemas

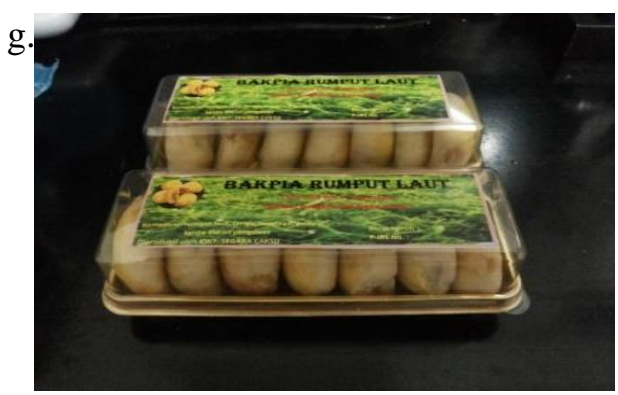

h. Bakpia yang sudah dikemas 
Gambar 2. Pelaksanaan Kegiatan Pelatihan Pengolahan rumput laut menjadi Bakpia.

\section{SIMPULAN DAN SARAN}

\subsection{Simpulan}

1. Kegiatan Pengabdian Kepada Masyarakat akan dilakukan dalam bentuk pelatihan dan diskusi pelatihan pengolahan pengolahan rumput laut menjadi bakpia di Desa Lembongan, , Kabupaten Klungkung. Kegiatan ini dilaksanakan pada hari 28-29 uli 2016 di Balai Desa Lembongan, Kabupaten Klungkung.

2. Kelompok wanita tani memiliki pengetahuan dan keterampilan dalam mengolah rumput laut menjadi bakpia rumput laut. Pengolahan rumput laut menjadi bakpia dapat memperpanjang masa simpan rumput laut dan meningkatkan nilai ekonomis rumput laut sehing pada akhirnya dapat meningkatkan keseahteraan petani rumput laut.

\subsection{Saran}

Perlu dilakukan tindak lanjut dari kegiatan ini berupa pelatihan manajemen pemasaran produk/bakpia yang dihasilkan sehingga dapat meningkatkan nilai jual dan pendapatan masyarakat desa Lembongan.

\section{UCAPAN TERIMA KASIH}

Keberhasilan pelaksanaan kegiatan pengabdian kepada masyarakat ini tentunya berkat kerjasama dari berbagai pihak. Untuk itu kami ucapkan terima kasih kepada Rektor Universitas Udayana melalui Lembaga Penelitian dan Pengabdian kepada Masyarakat atas dana yang diberikan dari Direktorat Riset dan Pengabdian Kepada Masyarakat Direktorat Jenderal Penguatan Riset dan Pengembangan Kementerian Riset, Teknologi dan Pendidikan Tinggi Sesuai dengan Surat Perjanjian Penugasan Pelaksanaan Pengabdian kepada Masyarakat. Nomor. 485.41/U14.2/PKM 08.00/2016, tanggal 16 Mei 2016. Terima kasih juga kami sampaikan kepada para anggota Kelompok Laki Tani "Dharma Kerti” dan Kelompok Wanita Tani "Segara Caksu” di desa Lembongan Kabupaten Klungkung yang telah berpartisipasi dalam kegiatan ini.

\section{DAFTAR PUSTAKA}

Anonimus. 2001. Teknologi Tepat Guna Agroindustri Kecil Sumatera Barat, Hasbullah, Dewan Ilmu Pengetahuan, Teknologi dan Industri Sumatera Barat.

Anonimus. 2010. Krupuk Rumput Laut Khas Bali. Liputan6.com, Badung. 
Anonimus. 2001. Profil Kabupaten Klungkung. Situs Resmi Pemerintah Kabupaten Klungkung

Desrosier, N.W., 1988. Teknologi Pengawetan Pangan. UI-Press, Jakarta.

Suryaalamsah, I. I. 2008. Pemanfaatan Rumput Laut Eucheuma cottonii Untuk Memperkaya Kandungan Iodium dan Serat Pangan Berbagai Jenis Mie. Skripsi S1. Departemen Teknologi Pangan dan Gizi, Fakultas Teknologi Pertanian IPB.

Wirajtmadi, Adriani M, Purwanti S. 2001. Pemanfaatan Rumput Laut (Eucheuma Cottonii) Dalam Meningkatkan Nilai Kandungan Serat Dan Yodium Tepung Terigu Dalam Pembuatan Mi Basah

Winarno, F.G., Fardiaz, S. dan Fardiaz, D. 1996. Teknologi Pengolahan Rumput Laut. Pustaka Sinar Harapan, Jakarta.

Anonimus. 2001. Teknologi Tepat Guna Agroindustri Kecil Sumatera Barat, Hasbullah, Dewan Ilmu Pengetahuan, Teknologi dan Industri Sumatera Barat.

Anonimus. 2010. Krupuk Rumput Laut Khas Bali. Liputan6.com, Badung.

Anonimus. 2001. Profil Kabupaten Klungkung. Situs Resmi Pemerintah Kabupaten Klungkung

Desrosier, N.W., 1988. Teknologi Pengawetan Pangan. UI-Press, Jakarta.

Suryaalamsah, I. I. 2008. Pemanfaatan Rumput Laut Eucheuma cottonii Untuk Memperkaya Kandungan Iodium dan Serat Pangan Berbagai Jenis Mie. Skripsi S1. Departemen Teknologi Pangan dan Gizi, Fakultas Teknologi Pertanian IPB.

Wirajtmadi, Adriani M, Purwanti S. 2001. Pemanfaatan Rumput Laut (Eucheuma Cottonii) Dalam Meningkatkan Nilai Kandungan Serat Dan Yodium Tepung Terigu Dalam Pembuatan Mi Basah

Winarno, F.G., Fardiaz, S. dan Fardiaz, D. 1996. Teknologi Pengolahan Rumput Laut. Pustaka Sinar Harapan, Jakarta. 